\title{
Investigation of hydrocarbon oil transformation by gliding arc discharge: comparison of batch and recirculated configurations
}

DOI:

10.1088/0022-3727/49/15/154001

\section{Document Version}

Accepted author manuscript

Link to publication record in Manchester Research Explorer

Citation for published version (APA):

Whitehead, C., \& Prantsidou, M. (2016). Investigation of hydrocarbon oil transformation by gliding arc discharge: comparison of batch and recirculated configurations. Journal of Physics D Applied Physics, 49(15), [154001]. https://doi.org/10.1088/0022-3727/49/15/154001

Published in:

Journal of Physics D Applied Physics

\section{Citing this paper}

Please note that where the full-text provided on Manchester Research Explorer is the Author Accepted Manuscript or Proof version this may differ from the final Published version. If citing, it is advised that you check and use the publisher's definitive version.

\section{General rights}

Copyright and moral rights for the publications made accessible in the Research Explorer are retained by the authors and/or other copyright owners and it is a condition of accessing publications that users recognise and abide by the legal requirements associated with these rights.

\section{Takedown policy}

If you believe that this document breaches copyright please refer to the University of Manchester's Takedown Procedures [http://man.ac.uk/04Y6Bo] or contact uml.scholarlycommunications@manchester.ac.uk providing relevant details, so we can investigate your claim.

\section{OPEN ACCESS}




\title{
Investigation of hydrocarbon oil transformation by gliding arc discharge: Comparison of batch and recirculated configurations.
}

\author{
J. Christopher Whitehead* and Maria Prantsidou
}

School of Chemistry, The University of Manchester, Manchester, M13 9PL.

\begin{abstract}
The degradation of liquid dodecane was studied in a gliding arc discharge (GAD) of humid argon or nitrogen. A batch or recirculating configuration was used. The products in the gaseous and liquid phase were analysed by infrared and chromatography and optical emission spectroscopy was used to identify the excited species in the discharge. The best degradation performance comes from the use of humid $\mathrm{N}_{2}$ but a GAD of humid argon produces fewer gas-phase products but more liquid-phase end-products. A wide range of products such as heavier saturated or unsaturated hydrocarbons both aliphatic and aromatic, and oxidation products mainly alcohols, but also aldehydes, ketones and esters are produced in the liquid-phase. The recirculating treatment mode is more effective than the batch mode increasing the reactivity and changing the product selectivities. Overall, the study shows promising results for the organic liquid waste treatment, especially in the recirculating mode.
\end{abstract}

Keywords: Gliding Arc Discharge, Dodecane, Plasma-Liquid treatment, OES, Hydrocarbon Oil

\section{Introduction}

The transformation of hydrocarbons into benign or reusable species is subject of much activity within the plasma chemistry community. The conversion of gaseous hydrocarbons such as methane and propane into hydrogen and syngas by reforming or into other organic species such as alcohols and acids by oxidative conversion has been studied using a wide range of plasma systems [1-5]. Significantly less attention has been paid to larger hydrocarbons, such as oils. Hydrocarbon oils can be found as waste in many processes that use a wide range of petroleum-based products in their systems as fuels, lubricants and pumping fluids. The management and treatment of this waste is complicated and expensive. Low temperature plasma technology can be an alternative solution to this problem. Moreover,

\footnotetext{
*email: j.c.whitehead@manchester.ac.uk
} 
the combination of the treatment of waste and its transformation into useful products would be of great benefit and it is a research area that needs to be further explored.

Some researchers in the past have studied the use of non-thermal plasma-liquid reforming of hydrocarbons oils for $\mathrm{H}_{2}$ production including the use of corona discharge [6-10], dielectric barrier discharge [11-13] and gliding arc discharge [14, 15]. However, no attention has been given to the plasma-liquid interaction or the chemistry taking place in the hydrocarbon oil during plasma treatment.

It should be noted that the scope of the plasma-liquid interactions is vast including a complex mechanism between gaseous and interfacial chemistry and the subsequent chemistry in the bulk liquid. The gaseous plasma contains reactive species such as electrons, ions, radicals and photons that can initially react with the liquid interface. Reaction can take place either as a gas-surface process leading to products that either return to the gas-phase or which penetrate into the bulk liquid by diffusion and convection mechanisms and undergo further reactions. A schematic summary of the plasma-liquid mechanism is given in Figure 1.

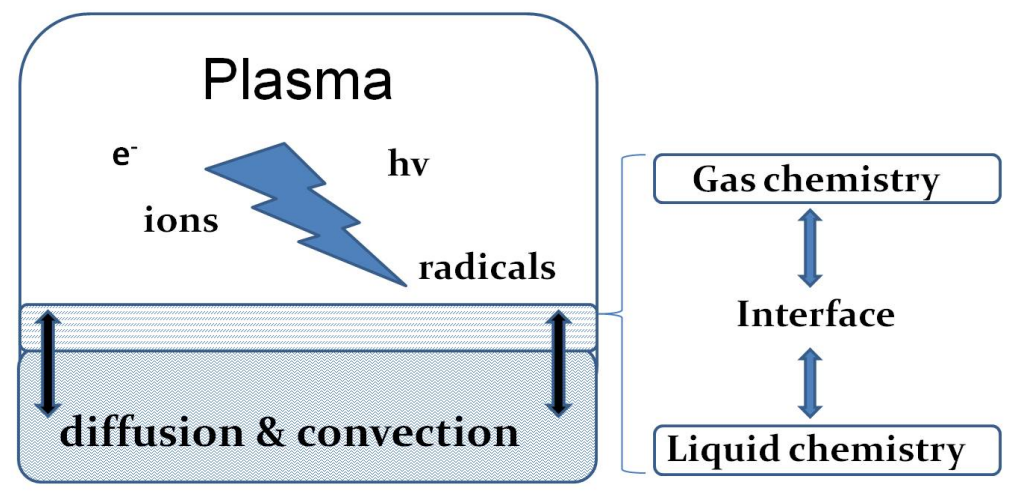

Figure 1. A schematic account of plasma-liquid interactions.

Mariotti et al. have discussed possible electron-liquid reactions in a plasma-liquid system for nanoparticles synthesis [16]. The electrons and charged particles in the gas phase have an isolated behaviour and their reactions are distinguished from reactions in the liquid phase. Electrons can penetrate into the plasma-liquid interface and solvent effects can diffuse the electron-initiated reactions into the bulk liquid. The solvation effect is not very well understood, but it is thought to be dependent on the electron kinetic energy [17]. Concerning the behaviour of the radicals produced in the plasma, several researchers has proven the dissolution of reactive species into the bulk liquid; for example, $\mathrm{OH}, \mathrm{HO}_{2}$ radicals and $\mathrm{NO}_{\mathrm{x}}$ 
species formed in the plasma-phase can react with liquid water to form $\mathrm{H}_{2} \mathrm{O}_{2}$ [18], $\mathrm{HNO}_{2}$ and $\mathrm{HNO}_{2}[19,20]$, respectively.

In our work, we use a gliding arc discharge (GAD) in humid nitrogen and argon to investigate the cool plasma treatment of $n$-dodecane $\left(\mathrm{C}_{12} \mathrm{H}_{26}\right)$, a common waste hydrocarbon oil. The effect on the oil of being processed in the GAD by either a batch or recirculating treatment has been investigated. Dodecane gliding arc plasma degradation has been studied separately in the gas and liquid phase. The correlation between the gaseous and liquid endproducts, as well as insights into the dodecane plasma-chemical degradation mechanism will be presented.

\section{Methods}

The gliding arc discharge (GAD) has been used for the treatment of liquid n-dodecane $\left(\mathrm{C}_{12} \mathrm{H}_{26}\right.$, Alfa Aesar $\left.\geq 99 \%\right)$ using two different approaches of batch and recirculating treatment, as illustrated in Figure 2 and Figure 3. The main GAD reactor consists of two stainless steel diverging electrodes, $50 \mathrm{~mm}$ long, $18 \mathrm{~mm}$ to $2.4 \mathrm{~mm}$ diverging width, $5 \mathrm{~mm}$ thick and with an adjustable minimum gap fixed at $3 \mathrm{~mm}$, located under a feeding gas nozzle of i.d. $1.5 \mathrm{~mm}$. An AC neon sign power supply provides a high voltage up to $20 \mathrm{kV}_{\mathrm{p}-\mathrm{p}}$ and 50 $\mathrm{mA}$ at a frequency of $50 \mathrm{~Hz}$. The plasma gases used were $\mathrm{N}_{2}$, and $\operatorname{Ar}(99.998 \%$ purity) in humid conditions achieved by bubbling the gas through a reservoir containing water, where the relative humidity was $\mathrm{RH}=75 \% \pm 2 \%\left(\mathrm{H}_{2} \mathrm{O}=2.3 \pm 0.3 \%\right)$, at $T=24^{\circ} \mathrm{C}$, measured with a HTD-625 thermo-hygrometer.
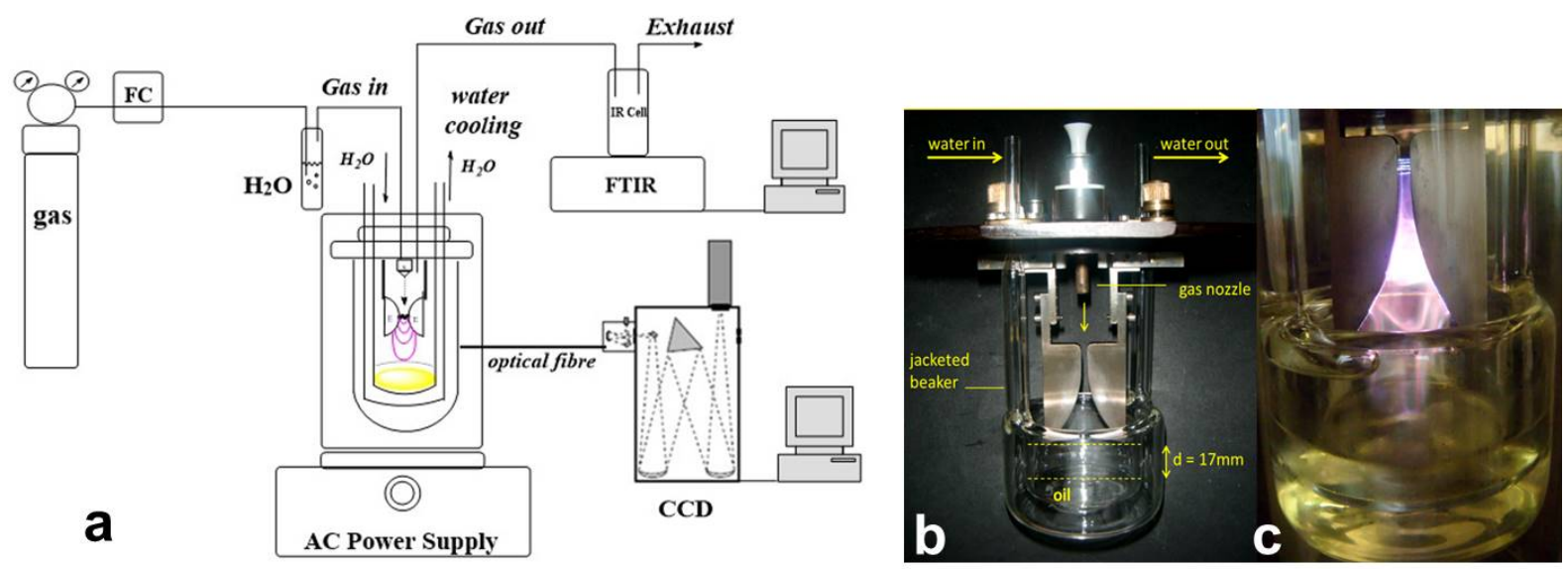
Figure 2. a) Schematic of the gliding arc reactor design for the batch plasma-liquid treatment of dodecane including the OES and FTIR detection schemes; b) picture of the water cooling jacketed cell used; c) photograph of $\mathrm{N}_{2} / \mathrm{H}_{2} \mathrm{O}$ GAD plasma batch liquid treatment.
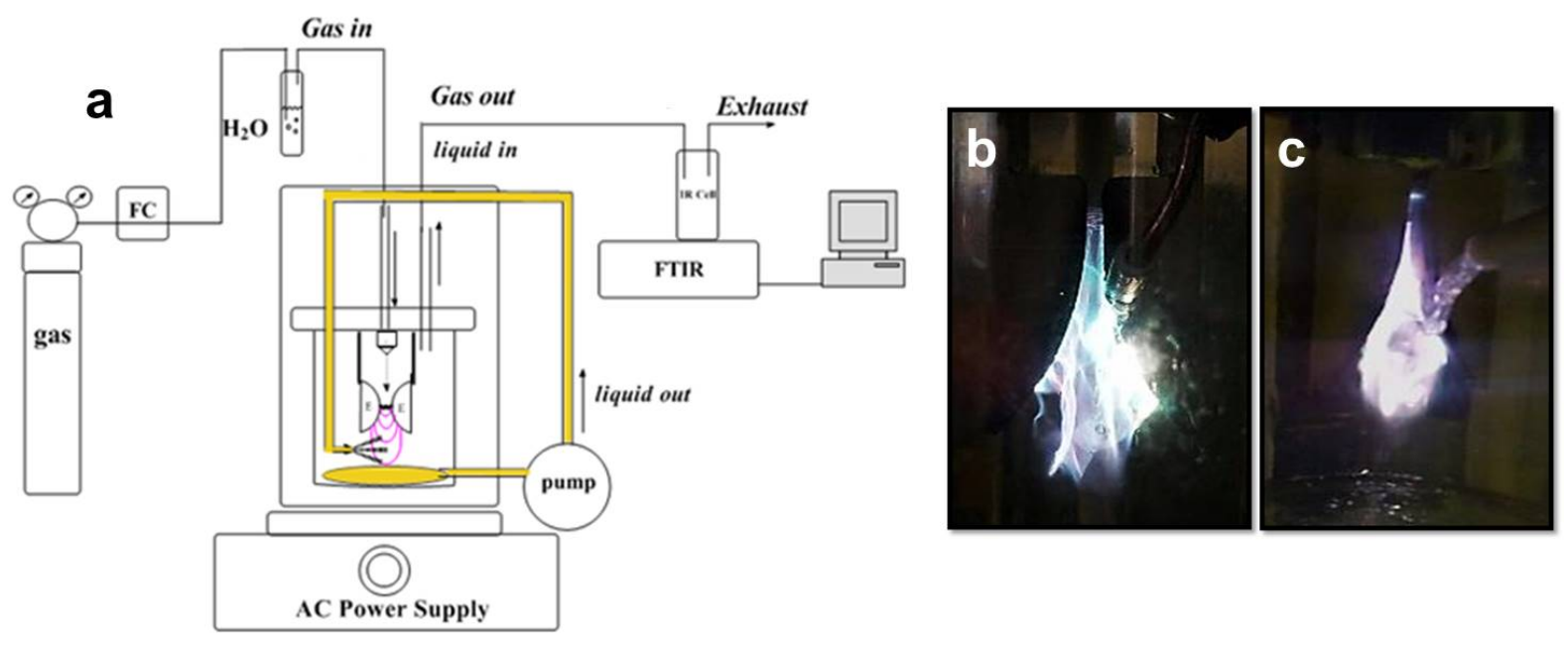

Figure 3. a) Schematic of the gliding arc reactor design for the recirculating plasma-liquid treatment of dodecane and photographs taken during b) $\mathrm{Ar} / \mathrm{H}_{2} \mathrm{O}$ and c) $\mathrm{N}_{2} / \mathrm{H}_{2} \mathrm{O}$ GAD plasma recirculating treatment of dodecane showing the direct injection of the oil into the plasma plume.

For the batch treatment of the oil, the GAD was run with a $5 \mathrm{~L} \mathrm{~min}^{-1}$ flow of the gas and 15 $\mathrm{ml}$ of dodecane was placed below the plasma plume, at a distance of $17 \mathrm{~mm}$ from the electrode with no direct contact of the plasma with the liquid. In order to facilitate the treatment and minimise the vaporisation, a jacketed cell was used with water-cooling at 22 ${ }^{\circ} \mathrm{C}$, as shown in Figure $2 \mathrm{~b}$. The plasma-liquid treatment of dodecane was run for $60 \mathrm{~min}$ with the maximum plasma input power achievable in each case viz. $220 \mathrm{~W}$ for $\mathrm{N}_{2} / \mathrm{H}_{2} \mathrm{O}$ and $140 \mathrm{~W}$ for $\mathrm{Ar} / \mathrm{H}_{2} \mathrm{O}$. For the recirculating oil plasma treatment, $60 \mathrm{ml}$ of dodecane were placed initially in the reaction vessel and a peristaltic pump was applied to drive the oil into a metal nozzle and recycle it using a flow of $120 \mathrm{ml} \mathrm{min}^{-1}$. The nozzle consisted of a copper tube (id $=1.7 \mathrm{~mm}$ ) with a mesh plate attached to the outlet.

Gaseous product analysis was performed using in-line FTIR spectroscopy. A FTIR spectrometer (Shimadzu 8300) with a long path IR cell $(5 \mathrm{~m})$ and a resolution of $1 \mathrm{~cm}^{-1}$ was used for the identification and concentration determination. Every measurement is an average 
of ten scans and is repeated five times to obtain an uncertainty in values $<2 \%$. Optical emission spectroscopy measurements of the discharge were performed for the liquid batch treatment. The position of the multi-mode quartz optical fibre allowed the integration of a 4 $\mathrm{cm}$ diameter optical field of the GAD downstream plume. The optical fibre was connected to a CCD Princeton Instrument 320PI spectrograph with either a 2400, 600 or $1500 \mathrm{~g} / \mathrm{mm}$ grating ( $0.03,0.13$ and $0.52 \mathrm{~nm}$ resolution, respectively) for a wavelength range of $200-800$ $\mathrm{nm}$. For the liquid analysis for both batch and recirculating treatment, samples were collected after 1 hour of treatment. GC-MS analysis was initially performed on the liquid samples to quantify percentage of liquid by-products formed from the dodecane. For a more detailed, qualitative chemical analysis, column chromatography was used to collect non-polar and polar fractions that were then subjected to ATR IR and GC-MS liquid analysis.

\section{Results and Discussion}

\subsection{Plasma-liquid batch and recirculating treatment of dodecane under $\mathrm{Ar} / \mathrm{H}_{2} \mathrm{O}$ and $\mathrm{N}_{2} / \mathrm{H}_{2} \mathrm{O}$ GAD plasma}

The recirculating treatment has been investigated in addition to the batch treatment of dodecane under $\mathrm{Ar} / \mathrm{H}_{2} \mathrm{O}$ and $\mathrm{N}_{2} / \mathrm{H}_{2} \mathrm{O}$ gliding arc plasma, as an attempt to improve the degradation efficiency. In the recirculating set-up, the injection of dodecane directly into the discharge area creates a direct plasma-liquid contact which is expected to increase the reaction surface and improve the degradation efficiency.

Table 1 compares the overall results in the plasma-liquid treatment of dodecane in the batch and recirculating modes. For both $\mathrm{Ar} / \mathrm{H}_{2} \mathrm{O}$ and $\mathrm{N}_{2} / \mathrm{H}_{2} \mathrm{O}$, the recirculating treatment increased the total volume of oil removed by a factor of 4.9 and 4.2, respectively, presumably by reducing plasma-induced evaporation of the oil. The best degradation efficiency is noted in case of $\mathrm{N}_{2} / \mathrm{H}_{2} \mathrm{O}$ recirculating treatment, where a total of $28.2 \mathrm{ml}$ oil was removed after $1 \mathrm{~h}$. In addition, the concentration of both gaseous and liquid products is increased in the recirculating mode.

\begin{tabular}{ccccc}
\hline GAD gas & $\begin{array}{c}\text { Pin / } \\
\mathbf{W}\end{array}$ & $\begin{array}{c}\text { total oil } \\
\text { removed } / \mathbf{m l} \text { at } \\
\mathbf{t = 6 0} \mathbf{~ m i n}\end{array}$ & $\begin{array}{c}\text { \% liquid end- } \\
\text { products after } \\
\text { treatment }\end{array}$ & $\begin{array}{c}\text { gaseous products } \\
\text { concentration } / \mathbf{p p m} \\
\mathbf{a t ~ t = 6 0 ~} \mathbf{~ m i n}\end{array}$ \\
\hline $\begin{array}{c}\mathrm{Batch} \\
\mathrm{Ar} / \mathrm{H}_{2} \mathrm{O}\end{array}$ & 140 & 2.01 & $<0.64$ & $712.4 \pm 28.5$ \\
\hline
\end{tabular}




\begin{tabular}{ccccc}
\hline $\begin{array}{c}\text { Batch } \\
\mathrm{N}_{2} / \mathrm{H}_{2} \mathrm{O}\end{array}$ & 220 & 6.63 & $<0.20$ & $1546.9 \pm 61.9$ \\
\hline $\begin{array}{c}\text { Recirculating } \\
\text { Ar/ } \mathrm{H}_{2} \mathrm{O}\end{array}$ & 140 & 9.96 & $<1.1$ & $960.3 \pm 38.4$ \\
\hline $\begin{array}{c}\text { Recirculating } \\
\mathrm{N}_{2} / \mathrm{H}_{2} \mathrm{O}\end{array}$ & 220 & 28.2 & $<0.5$ & $5287.05 \pm 206.2$ \\
\hline
\end{tabular}

Table 1. Summary of results of the GAD plasma-liquid degradation of dodecane using batch and recirculating treatment. The total volume of oil removed is calculated after 1 hour of treatment. Initial volume of dodecane was $15 \mathrm{ml}$ in the batch treatment and $60 \mathrm{ml}$ in the recirculating treatment. GC-MS analysis has been performed to quantify the amount of liquid by-products in the samples after the treatment.

\subsection{The gaseous chemistry of the GAD plasma-liquid batch and recirculating dodecane treatment}

A comparison of the gaseous end-product formation for the $\mathrm{Ar} / \mathrm{H}_{2} \mathrm{O}$ plasma batch and recirculating dodecane treatment is given in Figure 4. The degradation efficiency is increased in the case of the recirculating treatment, and the steady state concentrations of $\mathrm{CO}, \mathrm{CH}_{4}$ and $\mathrm{C}_{2} \mathrm{H}_{2}$ have been increased by a factor of $\sim 2$. Interestingly, the selectivity towards the endproducts has also changed, and instead of the $\mathrm{CO}$ and $\mathrm{CH}_{4}$ rich off-gas found during the batch treatment, the off-gas becomes rich in $\mathrm{CO}$ and $\mathrm{C}_{2} \mathrm{H}_{4}$ during the recirculation; the concentration of $\mathrm{C}_{2} \mathrm{H}_{4}$ having increased by a factor of 15 . Moreover, the concentration of gaseous dodecane is very low in the recirculating treatment off-gas compared to that for the batch treatment. This is probably due to the direct reaction of plasma with dodecane which causes increased degradation and less vaporisation than in the batch liquid treatment. 


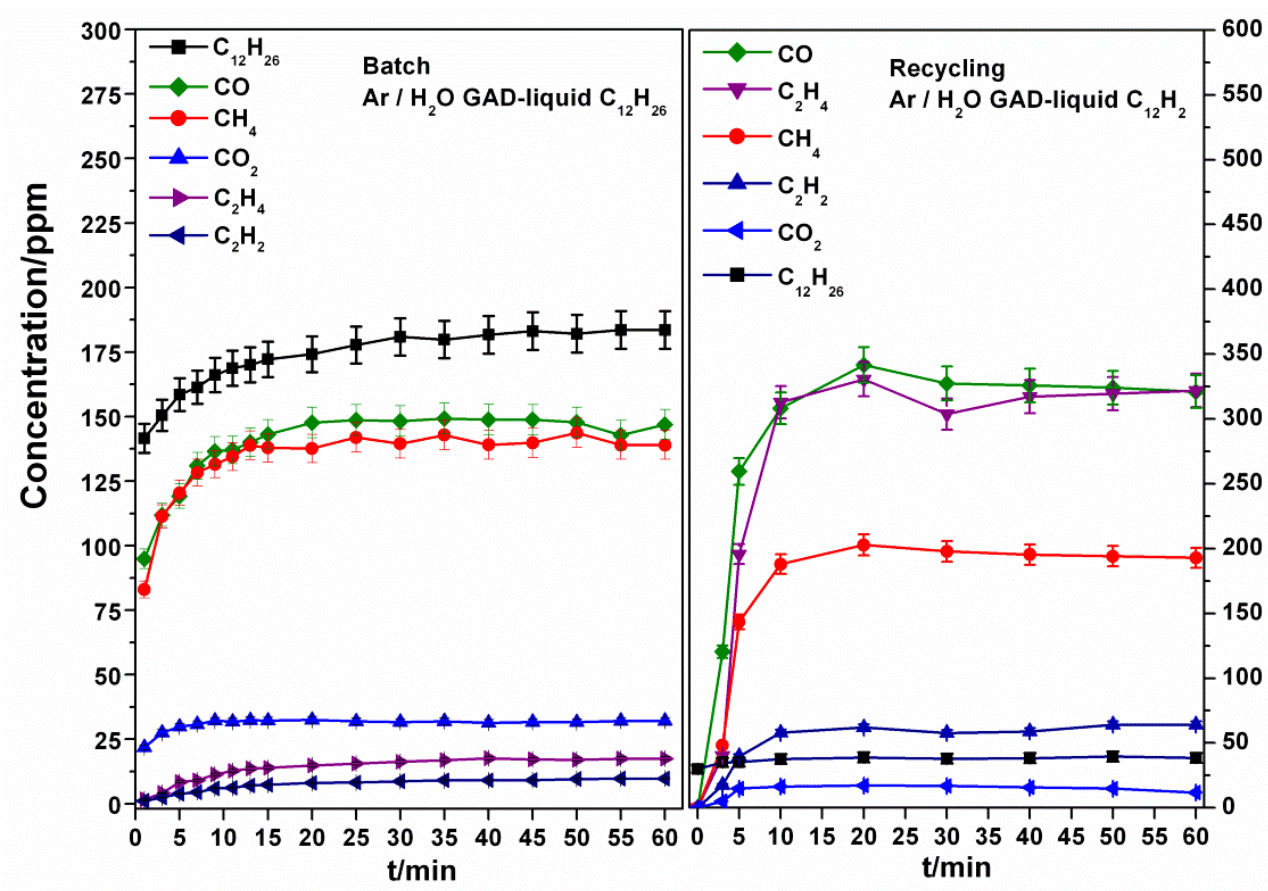

Figure 4.Gaseous products comparison between $\mathrm{Ar} / \mathrm{H}_{2} \mathrm{O}$ GAD batch (left-hand panel) and recirculating (right hand panel) for $P_{\text {in }}=140 \mathrm{~W}$.

Figure 5 shows the comparison of the gaseous products from the dodecane plasma-liquid treatment in humid nitrogen for the batch and the recirculating approach. The humid nitrogen plasma treatment of dodecane forms the same range of gaseous products in both the batch and recirculating set-ups. However, the overall composition of the off-gas changes. The degradation efficiency is again increased by the recirculating treatment and the off-gas is rich in $\mathrm{C}_{2} \mathrm{H}_{4}$ and $\mathrm{HCN}$ rather than $\mathrm{CO}$ and $\mathrm{C}_{2} \mathrm{H}_{4}$ in the case of the batch treatment with the maximum concentrations of $\mathrm{C}_{2} \mathrm{H}_{4}$ and $\mathrm{HCN}$ being increased by a factor of $\sim 6$ and $\sim 10$, respectively. Similarly to the $\mathrm{Ar} / \mathrm{H}_{2} \mathrm{O}$ plasma recirculating treatment, the concentration of gaseous dodecane is again low indicating that recirculating treatment causes a lower degree of vaporisation and a faster degradation rate than the batch treatment, due to the direct contact of dodecane with the plasma plume. 


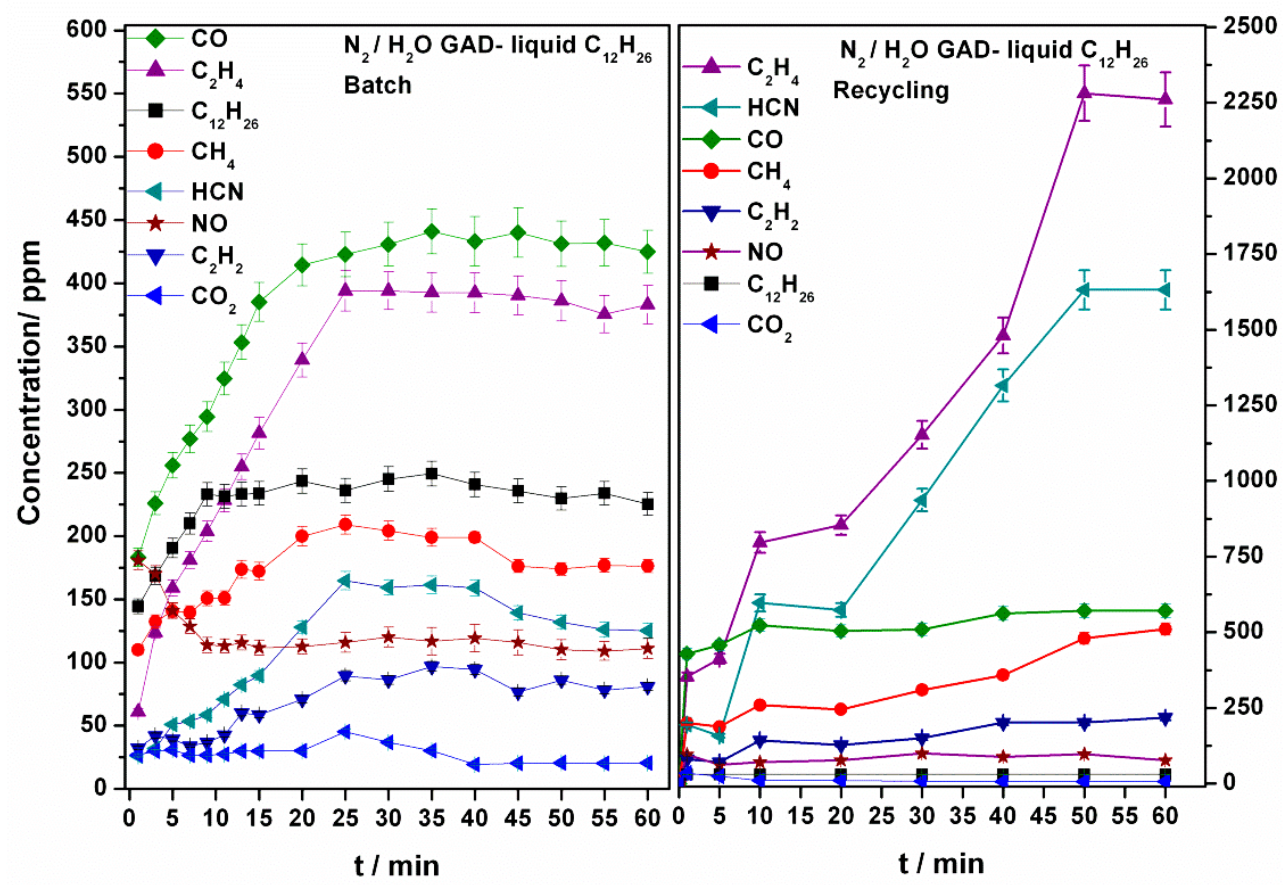

Figure 5. Gaseous products comparison between $\mathrm{N}_{2} / \mathrm{H}_{2} \mathrm{O}$ GAD during 60 min of batch (left-hand panel) and recirculating treatment (right-hand panel) for $P_{\text {in }}=200 \mathrm{~W}$.

Optical emission spectroscopy (OES) measurements have also been obtained during the Ar / $\mathrm{H}_{2} \mathrm{O}$ and $\mathrm{N}_{2} / \mathrm{H}_{2} \mathrm{O}$ plasma-liquid dodecane batch treatments and these are compared with OES spectra from GAD in gaseous $\mathrm{Ar} / \mathrm{H}_{2} \mathrm{O}$ and $\mathrm{N}_{2} / \mathrm{H}_{2} \mathrm{O}$ and for GAD for $\mathrm{Ar} / \mathrm{H}_{2} \mathrm{O}$ and $\mathrm{N}_{2} /$ $\mathrm{H}_{2} \mathrm{O}$ containing gaseous dodecane [21]. Figure 6 presents the observed spectra for the different conditions for $\mathrm{Ar} / \mathrm{H}_{2} \mathrm{O}$.

The dominant band in the emission spectrum of a pure $\mathrm{Ar} / \mathrm{H}_{2} \mathrm{O}$ gliding arc discharge belongs to the $\mathrm{OH} A \rightarrow X$ emission at $315 \mathrm{~nm}$. Neutral argon lines (Ar I) also appear in the red to near infrared spectral region $690-850 \mathrm{~nm}$ belonging to transitions from the $3 p^{5} 4 p$ to the metastable state $3 p^{5} 4 s$ configuration with ionisation energies between $13.08-13.33 \mathrm{eV}$ depending on the transition. Emission from atomic hydrogen Balmer series, $\mathrm{H}_{\beta},(4 d \rightarrow 2 p)$ and $\mathrm{H}_{\alpha}(3 p \rightarrow 2 s)$ emissions and singlet atomic oxygen, O I $\left(2 s^{2} 2 p^{3} 3 p \rightarrow 2 s^{2} 2 p^{3} 3 s\right)$ are also observed at 486, 656 $\mathrm{nm}$ and $777,844 \mathrm{~nm}$ respectively. The dissociation of water by electrons and excited argon in the plasma creates $\mathrm{OH}, \mathrm{H}$ and $\mathrm{O}$ radicals, either from electron impact or energy transfer reactions as shown in (R.1) and (R.2).

$$
\begin{array}{ll}
\text { R.1 } & \text { e }+\mathrm{H}_{2} \mathrm{O} \rightarrow \mathrm{OH}+\mathrm{H}+\mathrm{e} \\
\text { R.2 } & \mathrm{Ar} *+\mathrm{H}_{2} \mathrm{O} \rightarrow \mathrm{OH}+\mathrm{H}+\mathrm{Ar}
\end{array}
$$




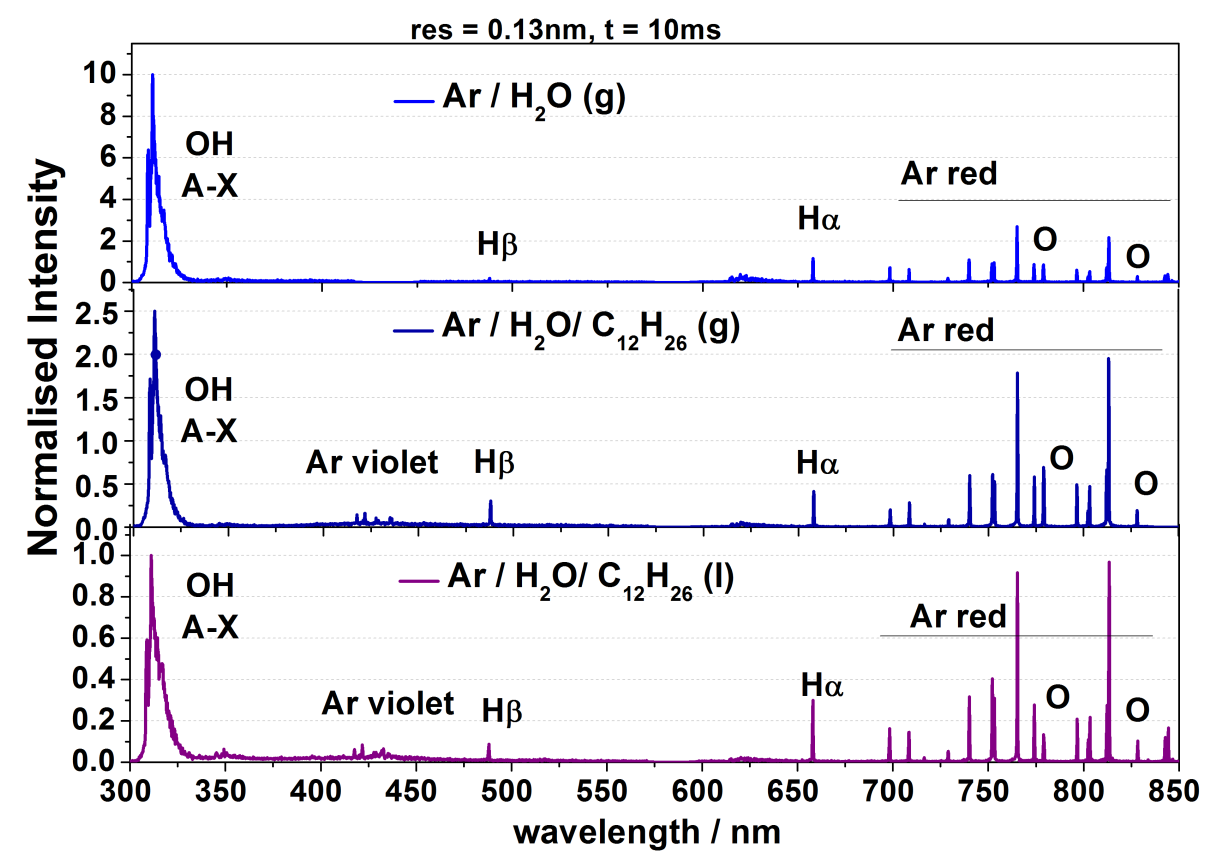

Figure 6. Optical emission spectra of (upper panel): a humid argon plasma $\left(\mathrm{H}_{2} \mathrm{O}=2.3 \pm\right.$ $0.3 \%$ ); (middle panel) a humid argon plasma with the addition of gaseous dodecane (90 ppm); and (lower panel) humid argon plasma-liquid batch treatment of dodecane. Spectral resolution is $0.13 \mathrm{~nm}$. The intensities of the spectra have been scaled to account for the different exposure times used.

The intensity of the $\mathrm{OH}(A \rightarrow X)$ emission observed in humid argon plasma is decreased by a factor of 4 and a factor or 10 in case of the gaseous and liquid treatment of dodecane respectively. The decrease in the relative concentration of the $\mathrm{OH}(A \rightarrow X)$ emission suggests that $\mathrm{OH}$ is a key reagent with gaseous dodecane to form $\mathrm{CO}, \mathrm{CO}_{2}$ products. In case of the treatment of liquid dodecane, it is also possible that quenching reactions can occur in the liquid interface and $\mathrm{OH}$ radicals can diffuse to react with the bulk liquid.

OES measurements have also been taken during the $\mathrm{N}_{2} / \mathrm{H}_{2} \mathrm{O}$ GAD plasma liquid treatment and Figure 7 presents comparative spectra in different configurations. Dissociation of water in $\mathrm{N}_{2} / \mathrm{H}_{2} \mathrm{O}$ GAD can occur by energy transfer reactions initiated by the nitrogen metastables (R.3 and R.4) or by electron impact reactions (R.5), leading to $\mathrm{OH}$, and subsequently $\mathrm{H}, \mathrm{O}$ radicals.

R.3 $\mathrm{N}_{2}(\mathrm{~A})+\mathrm{H}_{2} \mathrm{O} \rightarrow \mathrm{N}_{2}(\mathrm{X})+\mathrm{OH}+\mathrm{H}$

R.4 $\mathrm{N}\left({ }^{2} \mathrm{D}\right)+\mathrm{H}_{2} \mathrm{O} \rightarrow \mathrm{NH}+\mathrm{OH}$ 


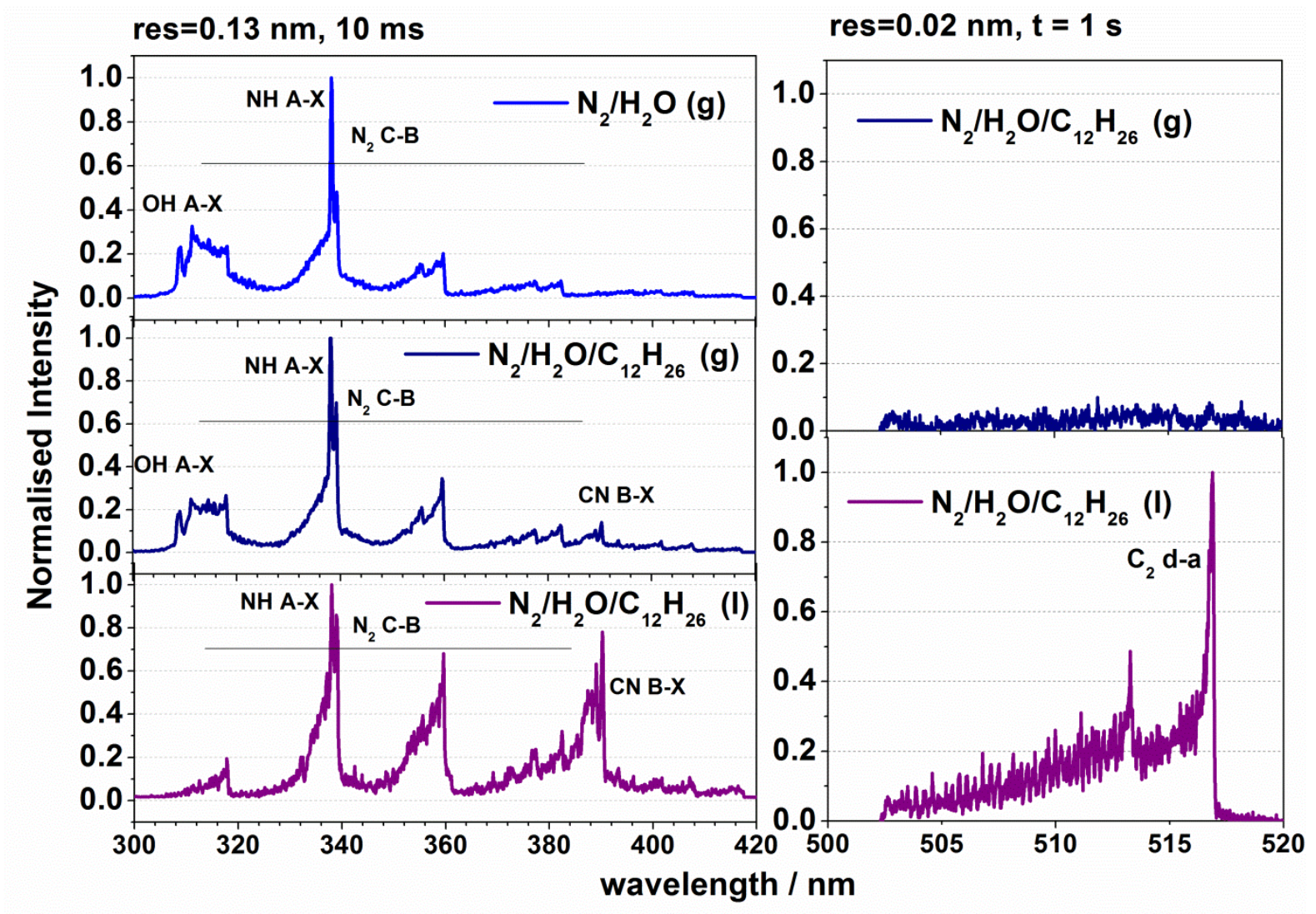

Figure 7. Optical emission spectra of: (upper left-hand panel) a humid $\mathrm{N}_{2}$ plasma $\left(\mathrm{H}_{2} \mathrm{O}=2.3\right.$ $\pm 0.3 \%$ ); (middle left-hand and upper right-hand panels) a humid $\mathrm{N}_{2}$ plasma with gaseous dodecane $(90 \mathrm{ppm})$ and (lower left-hand and right-hand panels) humid $\mathrm{N}_{2}$ plasma-liquid batch treatment of dodecane. Spectral resolution is $0.13 \mathrm{~nm}$ for $300-420 \mathrm{~nm}$ and $0.02 \mathrm{~nm}$ when adifferent grating was used in the range of $502-520 \mathrm{~nm}$ to enable the detection of the $\mathrm{C}_{2}$ bands. The intensities of the spectra have been scaled to account the different exposure times used.

Most commonly in $\mathrm{N}_{2}$ discharges, the dominant emission comes from the second positive $\mathrm{N}_{2}$ $C \rightarrow B$ in the UV region $[23,24]$. This is not observed in the humid nitrogen GAD generated in this case. Instead, the dominant emission belongs to the $\mathrm{NH} A \rightarrow X$ system. The $\mathrm{OH} A \rightarrow$ $X$ system is also observed in the UV but no $\mathrm{H}$ or $\mathrm{O}$ atomic emission is observed. It should be noted that electronically-excited $\mathrm{NO}^{*}$ as intermediate cannot be seen due to the transmittance of the Pyrex vessel used. The fact that $\mathrm{NO}$ but not $\mathrm{NH}_{3}$ is formed as an end product as detected by FTIR, suggests that $\mathrm{NH}^{*}$ may be an intermediate related to reaction R.4, 
producing $\mathrm{NO}$ rather than $\mathrm{NH}_{3}$ as a reaction end-product. The $\mathrm{NH}$ radical could be oxidised to $\mathrm{NO}$ according to reactions (R.6), (R.7) and (R.8). NO can be formed by $\mathrm{N}$ and $\mathrm{O}$ or $\mathrm{OH}$ radical recombination, as shown in reactions (R.9) and (R.10). However, the oxidative environment is not sufficient to form further oxidation to $\mathrm{NO}_{2}$, which normally forms as common by-product in air discharges [25].
R.6 $\quad \mathrm{NH}+\mathrm{OH} \rightarrow \mathrm{H}+\mathrm{HNO}$
$\mathrm{k}_{300}=3.3 \times 10^{-11} \mathrm{~cm}^{3}$ molecule $\mathrm{s}^{-1} \quad$ [26]
R.7 $\mathrm{HNO}+\mathrm{O} \rightarrow \mathrm{OH}+\mathrm{NO}$
$\mathrm{k}_{300}=3.8 \times 10^{-11} \mathrm{~cm}^{3}$ molecule $\mathrm{s}^{-1}$
R.8 $\quad \mathrm{NH}+\mathrm{O} \rightarrow \mathrm{NO}+\mathrm{H}$
$\mathrm{k}_{300}=1.6 \times 10^{-10} \mathrm{~cm}^{3}$ molecule $\mathrm{e}^{-1} \mathrm{~s}^{-1}$
R.9 $\mathrm{N}+\mathrm{OH} \rightarrow \mathrm{NO}+\mathrm{H}$
$\mathrm{k}_{300}=4.4 \times 10^{-11} \mathrm{~cm}^{3}$ molecule $\mathrm{e}^{-1} \mathrm{~s}^{-1}$
R.10 N $+\mathrm{O}+\mathrm{M} \rightarrow \mathrm{NO}+\mathrm{M}$
$\mathrm{k}_{300}=7 \times 10^{-10} \mathrm{~cm}^{3}$ molecule $\mathrm{s}^{-1}$

The addition of $90 \mathrm{ppm}$ of dodecane to the $\mathrm{N}_{2} / \mathrm{H}_{2} \mathrm{O}$ plasma does not cause a significant change to the emission spectrum where again the dominant emission belongs mainly to the NH $A \rightarrow X$ system and the $\mathrm{N}_{2} C \rightarrow B$ system. The intensity of the $\mathrm{OH} A \rightarrow X$ emission in this case appears slightly decreased as $\mathrm{OH}$ and $\mathrm{O}$ radicals react with dodecane to give $\mathrm{CO}, \mathrm{CO}_{2}$ and oxygenated end-products. However, in the spectrum of the $\mathrm{N}_{2} / \mathrm{H}_{2} \mathrm{O}$ plasma-liquid treatment, $\mathrm{OH} A \rightarrow X$ emission is not observed. Quenching reactions with the liquid surface are likely to happen which could induce reactions in the liquid phase. $\mathrm{CN} B \rightarrow X$ emission is observed for the GAD treatment of dodecane in both gaseous and liquid treatments. $\mathrm{C}_{2} a \rightarrow d$ emission is only seen during the plasma-liquid treatment and the $\mathrm{CN} B \rightarrow X$ intensity is increased for plasma-liquid treatment compared with gaseous, showing a possible relationship of their increased relative intensity with the increased concentration of $\mathrm{HCN}$, $\mathrm{C}_{2} \mathrm{H}_{4}$ and $\mathrm{C}_{2} \mathrm{H}_{2}$ end-products observed in the gas phase [21].

\subsection{Understanding the liquid-phase chemistry involved in the plasma-liquid treatment of dodecane}

For both batch and recirculating treatment of liquid dodecane using $\mathrm{Ar} / \mathrm{H}_{2} \mathrm{O}$ and $\mathrm{N}_{2} / \mathrm{H}_{2} \mathrm{O}$ plasma, an effort has been performed to unravel the plasma-liquid chemistry, by identifying the liquid-phase end-products. For the batch and recirculating modes, analysis has been performed on the liquid samples collected after $60 \mathrm{~min}$ of plasma treatment of dodecane. Soot 
was found in all the liquid samples. XRD analysis of the soot showed that it is amorphous in form. The liquid samples were analysed in two ways; firstly, as crudes collected after treatment but also as polar fractions collected after column chromatography separation. IR and GC-MS spectroscopy was used.

Figure 8 shows the products identified by $\mathrm{GC}$ in the crude liquid samples after $\mathrm{N}_{2} / \mathrm{H}_{2} \mathrm{O}$ and $\mathrm{Ar} / \mathrm{H}_{2} \mathrm{O}$ GAD treatment. These are compared with a blank sample of dodecane. After the $\mathrm{N}_{2} / \mathrm{H}_{2} \mathrm{O}$ plasma batch treatment of dodecane, liquid products identified are similar to those observed in the case of the recirculating treatment. These are alkenes such as decene $\left(\mathrm{C}_{10} \mathrm{H}_{20}\right)$, undecene $\left(\mathrm{C}_{12} \mathrm{H}_{22}\right)$, alcohols such as tridecanol $\left(\mathrm{C}_{13} \mathrm{H}_{28} \mathrm{O}\right)$, tetradecanol $\left(\mathrm{C}_{14} \mathrm{H}_{30} \mathrm{O}\right)$, pentadecanol $\left(\mathrm{C}_{15} \mathrm{H}_{32} \mathrm{O}\right)$, hexadecanol $\left(\mathrm{C}_{16} \mathrm{H}_{34} \mathrm{O}\right)$ and triphenylmethanol $\left(\mathrm{C}_{19} \mathrm{H}_{16} \mathrm{O}\right)$. The aliphatic ester of bis(3-ethylhexyl) adipate $\left(\mathrm{C}_{22} \mathrm{H}_{42} \mathrm{O}_{4}\right)$ is also identified. These species are also seen in case of the $\mathrm{Ar} / \mathrm{H}_{2} \mathrm{O}$ recirculating treatment of dodecane, as well as some higher oxidation level products such as undecanal and isomers of $\mathrm{C}_{12} \mathrm{H}_{24} \mathrm{O}$.

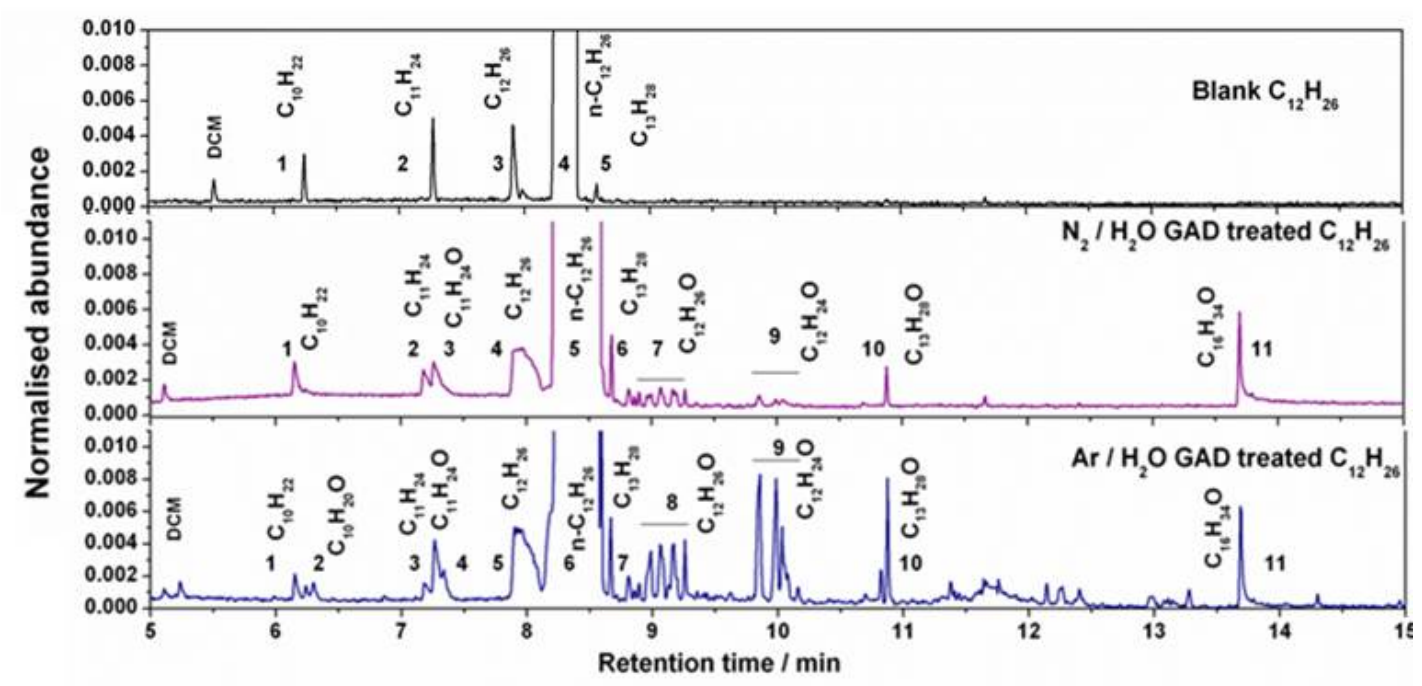

Figure 8. Normalised GC chromatograms of crude liquid samples in case of a no treatment (upper panel), $\mathrm{N}_{2} / \mathrm{H}_{2} \mathrm{O}$ plasma treatment (middle panel) and $\mathrm{Ar} / \mathrm{H}_{2} \mathrm{O}$ plasma treatment of dodecane (lower panel).

All the crude samples were then subjected to liquid column chromatography and polar fractions were collected for IR and GC-MS analysis. The IR spectra for each condition are presented for comparison in Figure 9 and 10. 

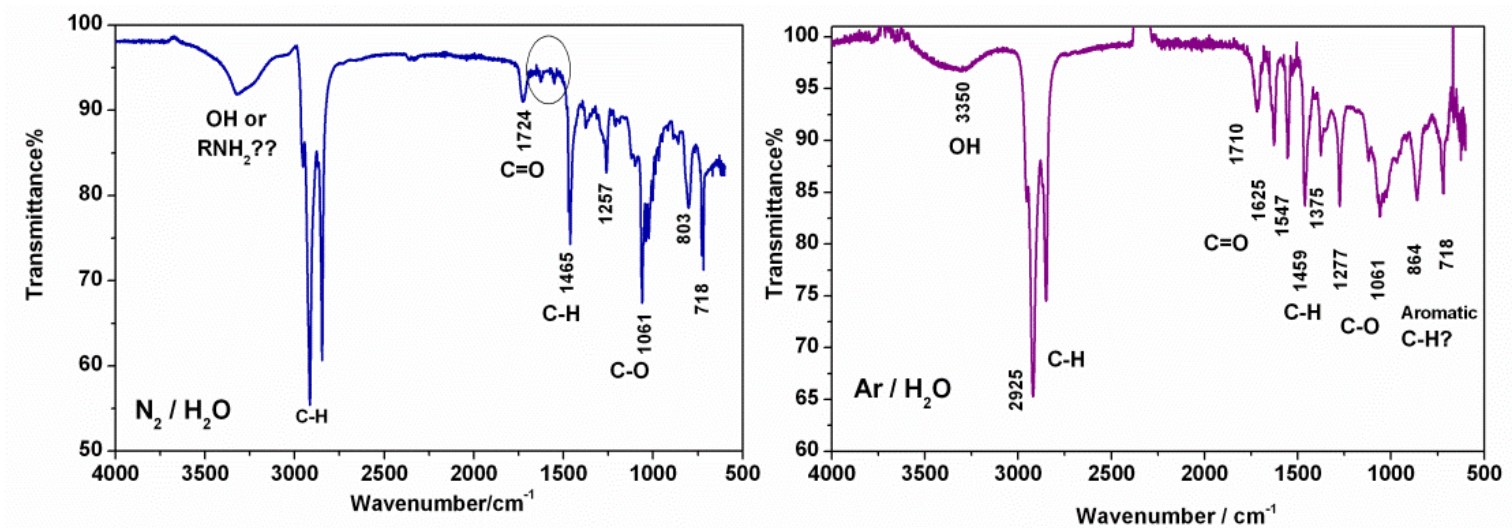

Figure 9. IR spectra of polar fractions of liquid samples after $\mathrm{N}_{2} / \mathrm{H}_{2} \mathrm{O}$ (left-hand panel) and $\mathrm{Ar} / \mathrm{H}_{2} \mathrm{O}$ (right-hand panel) GAD-batch treatment of dodecane after $60 \mathrm{~min}$.

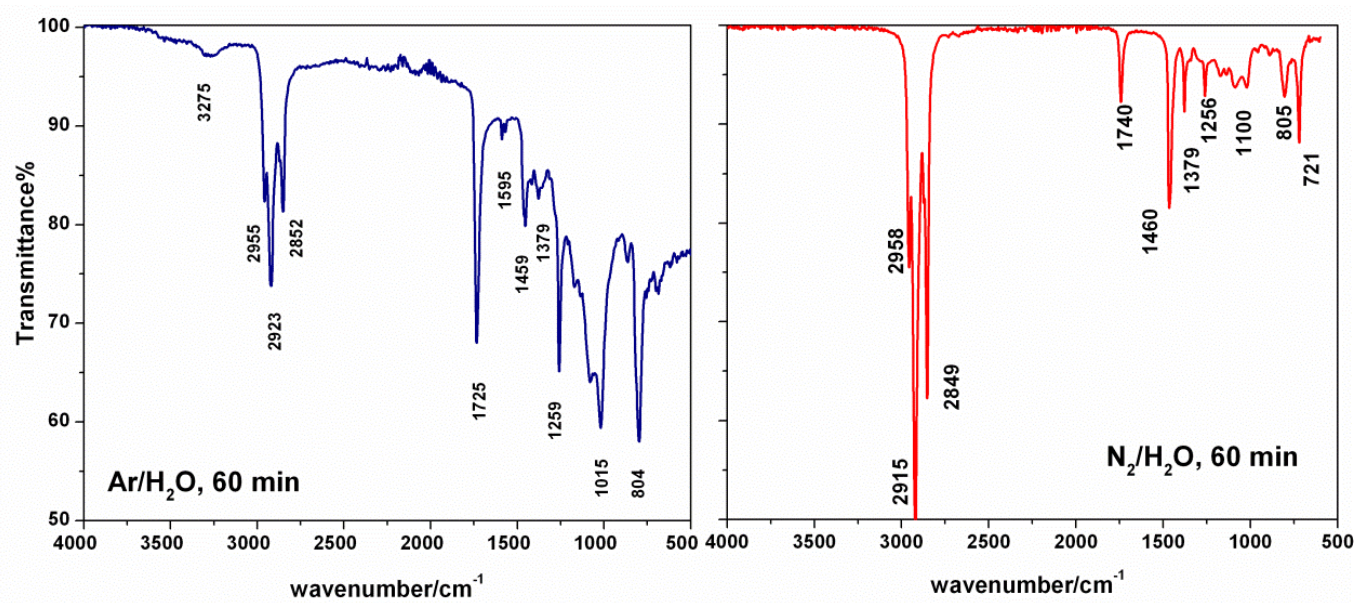

Figure 10 IR spectra of polar fractions of liquid samples after $\mathrm{Ar} / \mathrm{H}_{2} \mathrm{O}$ (left-hand panel) and $\mathrm{N}_{2} / \mathrm{H}_{2} \mathrm{O}$ (right-hand panel) GAD-recirculating treatment of dodecane after 60 min.

Features due to $\mathrm{C}-\mathrm{H}$ stretching at $\sim 2800 \mathrm{~cm}^{-1}$, bending at $\sim 1380,1430 \mathrm{~cm}^{-1}, \mathrm{C}=\mathrm{O}$ stretching at $\sim 1730 \mathrm{~cm}^{-1}$, and C-O stretching at $\sim 1260,1015 \mathrm{~cm}^{-1}$ are detected in all spectra. The peak at $\sim 1260 \mathrm{~cm}^{-1}$ which lies at higher wavenumber indicates a delocalised ether bond such as $=\mathrm{C}$ O-C. In case of the $\mathrm{Ar} / \mathrm{H}_{2} \mathrm{O}$ spectrum, the polar functional groups have higher intensity compared to the $\mathrm{N}_{2} / \mathrm{H}_{2} \mathrm{O}$ plasma. Moreover, only in case of $\mathrm{Ar} / \mathrm{H}_{2} \mathrm{O}$, there is a weak band observed at $1595 \mathrm{~cm}^{-1}$ indicating the existence of aromatic rings.

The liquid products identified by GC-MS in the polar fractions of liquid samples after $60 \mathrm{~min}$ of batch or recirculating plasma dodecane treatment are shown in Figure 11 and 12. 

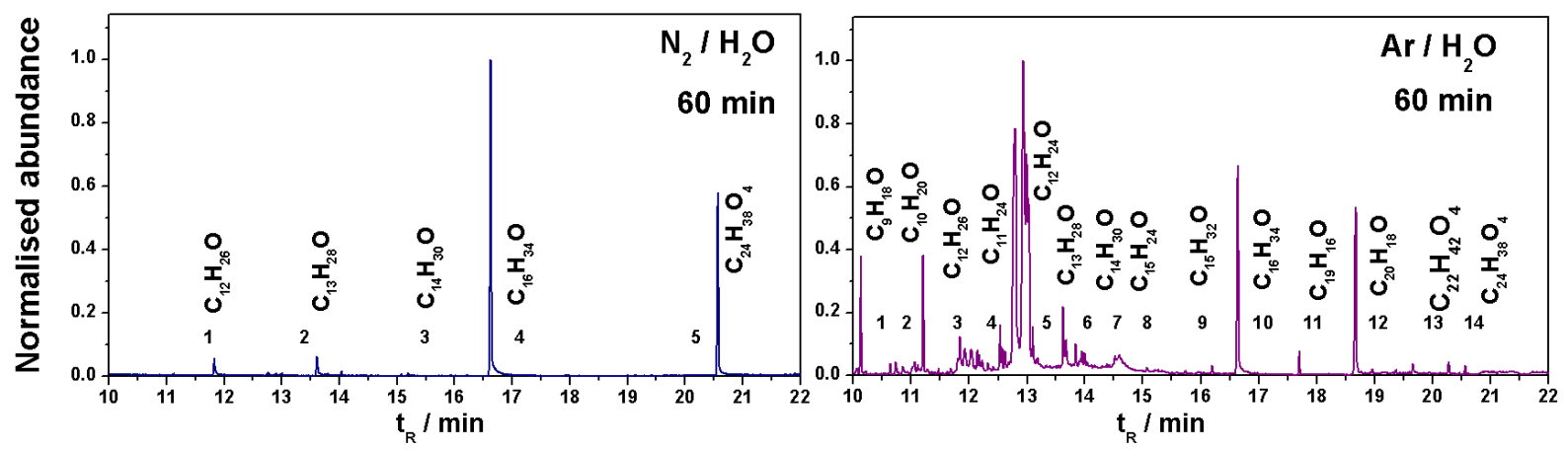

Figure 11. Normalised GC chromatograms of polar fractions of liquid samples after $\mathrm{N}_{2} / \mathrm{H}_{2} \mathrm{O}$ (left-hand panel) and $\mathrm{Ar} / \mathrm{H}_{2} \mathrm{O}$ (right-hand panel) GAD-batch treatment of dodecane.
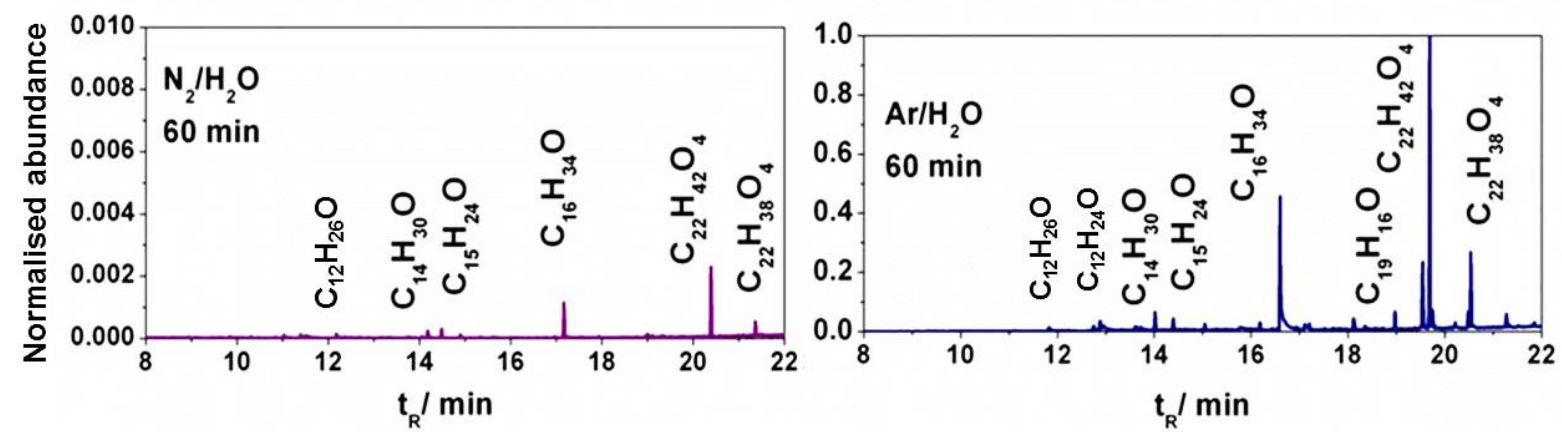

Figure 12. Normalised GC chromatograms of polar fractions of samples taken during the $\mathrm{N}_{2} / \mathrm{H}_{2} \mathrm{O}$ (left-hand panel) and $\mathrm{Ar} / \mathrm{H}_{2} \mathrm{O}$ (right-hand panel) GAD-recirculating treatment of dodecane at $60 \mathrm{~min}$.

In all cases, the formation of primary aliphatic alcohols is dominant and hexadecanol $\left(\mathrm{C}_{16} \mathrm{H}_{34} \mathrm{O}\right)$ especially is formed with the highest abundance. In the case of $\mathrm{N}_{2} / \mathrm{H}_{2} \mathrm{O}$ plasma treatment, other alcohols identified are dodecanol $\left(\mathrm{C}_{12} \mathrm{H}_{26} \mathrm{O}\right)$, tridecanol $\left(\mathrm{C}_{13} \mathrm{H}_{28} \mathrm{O}\right)$ and tetradecanol $\left(\mathrm{C}_{14} \mathrm{H}_{30} \mathrm{O}\right)$, and also isomers of dodecanone $\left(\mathrm{C}_{12} \mathrm{H}_{24} \mathrm{O}\right)$. Remarkably, the aromatic compound of triphenylmetahnol $\left(\mathrm{C}_{19} \mathrm{H}_{16} \mathrm{O}\right)$ and the formation of a phthalate ester 6methylheptyl2-(2-(heptyloxy)-2-oxoethyl)benzoate $\left(\mathrm{C}_{24} \mathrm{H}_{38} \mathrm{O}_{4}\right)$ is also identified. It must be noted that phthalates are commonly considered as contaminants in routine GC-MS as they are used as plasticisers in the sample vials. However, the fact that the IR spectrum in this case presents evidence of aromatic rings and the $=\mathrm{C}-\mathrm{O}-\mathrm{C}$ bond, and the fact that no contamination is observed in repeated blank samples, leads us to conclude that the phthalate is a liquid reaction by-product. It must be noted that the $\mathrm{C}_{10}-\mathrm{C}_{12}$ aliphatic unsaturated hydrocarbons 
seen in the crude sample are most likely not present in the polar fraction after separation. In case of $\mathrm{Ar} / \mathrm{H}_{2} \mathrm{O}$ plasma treatment, in addition to the alcohols already mentioned before, pentadecanol $\left(\mathrm{C}_{15} \mathrm{H}_{32} \mathrm{O}\right)$ and also the aromatic alcohol 2,6-di-tert-butyl-4-methylphenol $\left(\mathrm{C}_{15} \mathrm{H}_{24} \mathrm{O}\right)$ is also identified. Furthermore, higher oxidation state products such as aldehydes or ketones seem to form in higher abundance in this case including nonanal $\left(\mathrm{C}_{9} \mathrm{H}_{18} \mathrm{O}\right)$ and decanal $\left(\mathrm{C}_{10} \mathrm{H}_{20} \mathrm{O}\right)$. Several isomers of $\mathrm{C}_{12} \mathrm{H}_{24} \mathrm{O}$ have been observed including 2-dodecanone and 4- dodecanone were identified. Moreover, aromatic alcohols such as triphenylmethanol $\left(\mathrm{C}_{19} \mathrm{H}_{16} \mathrm{O}\right)$ and 2,2,2-triphenylethanol $\left(\mathrm{C}_{20} \mathrm{H}_{18} \mathrm{O}\right)$ are also identified. A new ester of bis(3ethylhexyl) adipate $\left(\mathrm{C}_{22} \mathrm{H}_{42} \mathrm{O}_{4}\right)$ as well as the one seen in case of $\mathrm{N}_{2} / \mathrm{H}_{2} \mathrm{O}$, phthalate ester bis(6-methylheptyl) $\left(\mathrm{C}_{24} \mathrm{H}_{38} \mathrm{O}_{4}\right)$, is also seen in low abundance.

It can be noted that in both batch and recirculating treatment the $\mathrm{Ar} / \mathrm{H}_{2} \mathrm{O}$ plasma creates a higher abundance and wider range of liquid oxygenated products compared to $\mathrm{N}_{2} / \mathrm{H}_{2} \mathrm{O}$ plasma. This could be possibly due to the fact that the rate of oxidation induced by the plasma reactive species in the liquid phase is slower in case of $\mathrm{N}_{2} / \mathrm{H}_{2} \mathrm{O}$ plasma, due to a slower diffusion rate that could be caused by dynamic vaporisation. In the case of the recirculating treatment for both $\mathrm{N}_{2} / \mathrm{H}_{2} \mathrm{O}$ and $\mathrm{Ar} / \mathrm{H}_{2} \mathrm{O}$ plasma, the range and abundance of low chain oxygenated products is reduced in favour of the higher chain products compared to the batch treatment.

Overall, a wide range of different end-products have been identified in the plasma posttreated dodecane. These fall into categories of alkanes, alkenes, aromatic hydrocarbons and different oxidation level products such as both aliphatic and aromatic alcohols, ethers, aldehydes, ketones and esters. Figure 13 summarises the major liquid products observed. 


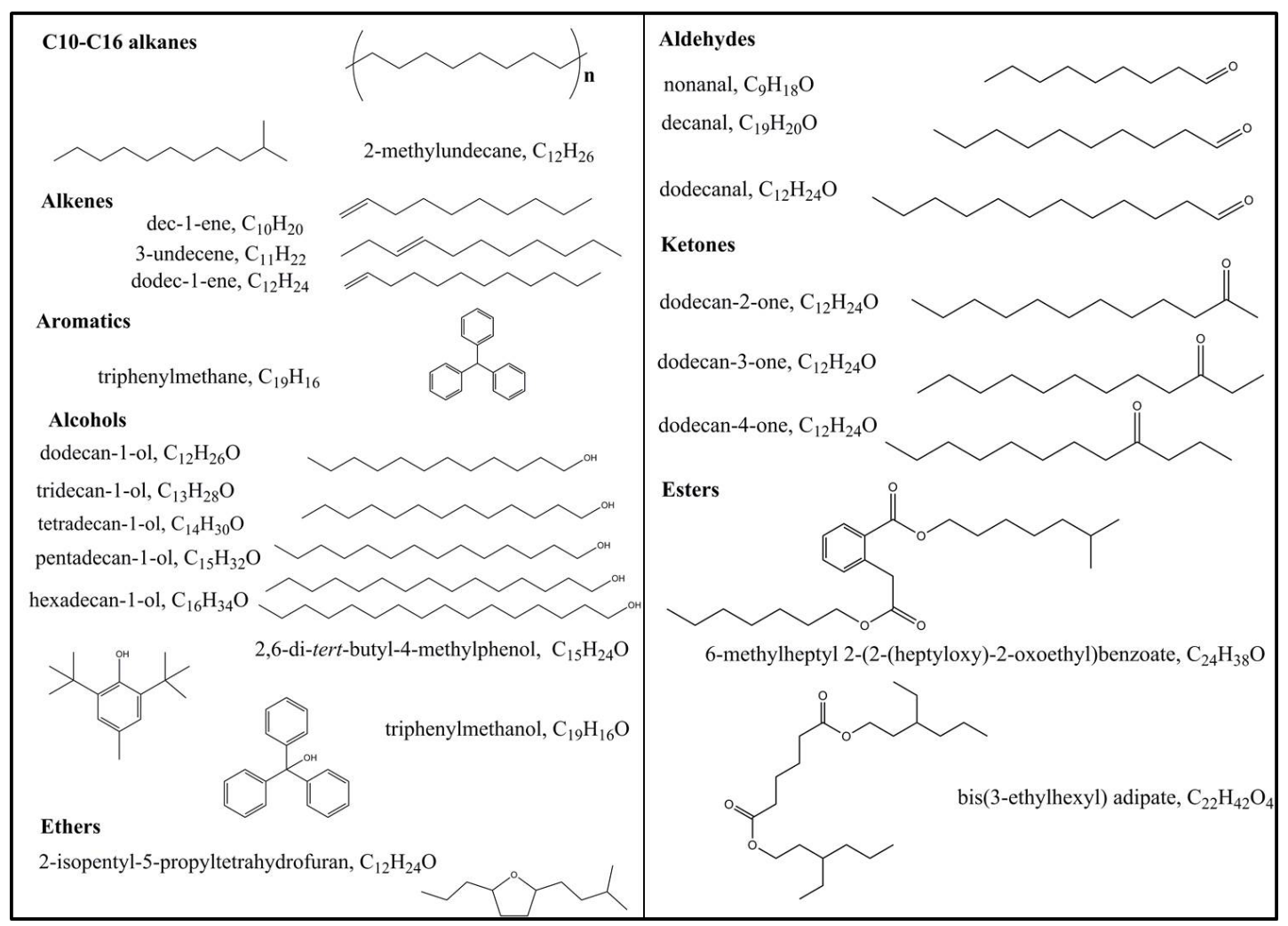

Figure 13. A summary of the major liquid products identified in the plasma post treated dodecane

Electron impact reactions or hydrogen abstraction reactions of $\mathrm{N}, \mathrm{OH}$ or $\mathrm{O}$ radicals formed in the discharge in different conditions can initiate the dodecane fragmentation leading to fragments varying from methyl radicals to undecyl radicals. Recombination reactions between these radicals can lead to the formation of heavier alkanes. Further hydrogen abstraction from alkyl radicals can lead to the formation of alkenes and molecular hydrogen, as shown in reaction (R.11). The hydroxyl radical formed in the discharge by water dissociation can add to the alkyl radicals to form the respective alcohols (reaction R.12).

R.11<smiles>CC(C)=C(C)C</smiles><smiles>C[C]([C@H](O)C(C)(C)C(C)(C)O)C(C)(C)C</smiles> 
Atomic oxygen also identified in humid conditions can add to alkyl radicals leading to alkoxy radicals that can then form alcohols if they are hydrogenated, aldehydes or ketones if dehydrogenated and ethers in they react further with another alkyl radical (reaction R.13).

\section{R.13}
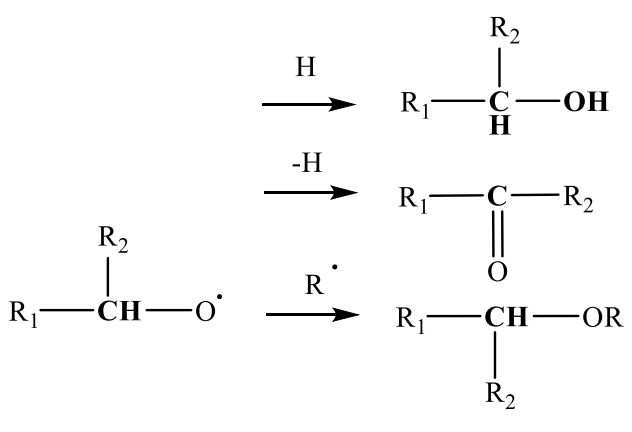

where $\mathrm{R}_{1}, \mathrm{R}_{2}$ could be alkyl radicals or hydrogen

The formation of a cyclic ether like the hydrofuran shown in Figure 13, shows that intermediate products such as alcohols with a double bond in position 1,4 are possible, which can further react to form the cyclic ether as shown in reaction (R.14).

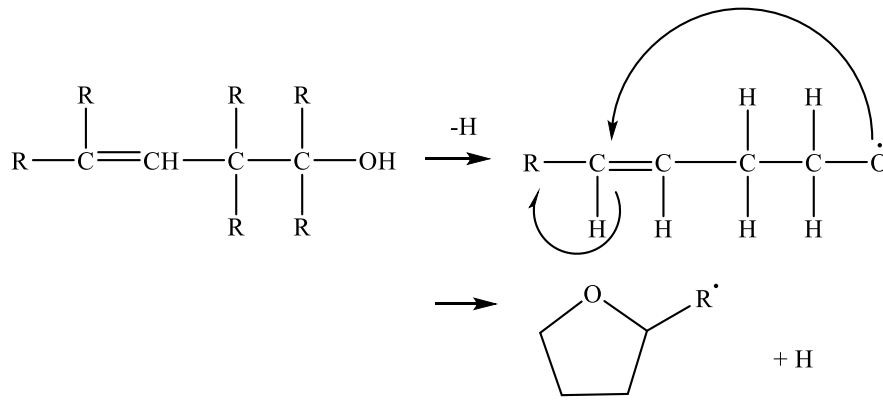

R.14

The formation of aromatic rings can occur after polymerisation reaction of acetylene, as shown in reaction R.15. However, no polyaromatics are observed which are commonly found in combustion systems [30].

R.15

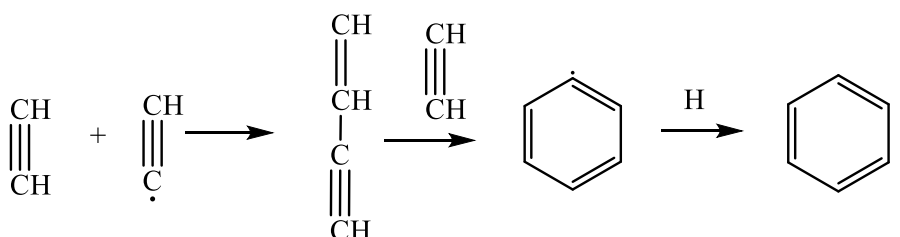

Subsequent addition of $\mathrm{OH}, \mathrm{O}$ radicals to the benzene ring can form aromatic alcohols and subsequent oxidation can lead to the formation of benzoic acid or esters, which could be a precursor for the benzoate formation shown in Figure 13. 


\section{Conclusions}

The plasma degradation of liquid dodecane has been studied using a gliding arc discharge, using both a batch and recirculating treatment. Results show that the reactive species formed in plasma can diffuse into the liquid interface to initiate reactions which mainly breakdown dodecane to lighter gaseous products but also form heavier products remaining in the bulk liquid. Cascaded liquid-based chemistry presents a scenario largely dominated by molecular potentials and reaction activation energies. This differs from the gas-phase chemistry in plasmas where the species and in particular charged species behave as isolated entities and the reactions are mainly determined by their kinetic energies $[16,31]$.

In the case of batch treatment, the best degradation efficiency is noted for $\mathrm{N}_{2} / \mathrm{H}_{2} \mathrm{O}$ GAD causing a $44.2 \%$ reduction in the oil volume after $1 \mathrm{~h}$ of treatment. The $\mathrm{Ar} / \mathrm{H}_{2} \mathrm{O}$ GAD treatment of dodecane creates a lower concentration of total gaseous products compared to the $\mathrm{N}_{2} / \mathrm{H}_{2} \mathrm{O}$ GAD treatment, but a higher abundance of liquid end-products. It is suggested that the higher energy dissipated in the $\mathrm{N}_{2}$ plasma and the elevated gas temperature can affect the degradation mechanism both physically by causing a higher degree of vaporisation, but also chemically, by changing the selectivity of the gaseous products.

The recirculating treatment of dodecane creates a more effective method of plasma-liquid treatment, which increases the reactivity and changes the selectivities of the gaseous products. Compared to the batch treatment results, the degradation efficiency for both $\mathrm{Ar} / \mathrm{H}_{2} \mathrm{O}$ and $\mathrm{N}_{2} / \mathrm{H}_{2} \mathrm{O}$ plasma is increased by a factor of 4.2 and 4.9 , respectively. Liquid analysis of samples from both cases after 1hour treatment, shows that similar products are formed. A wide range of products such as heavier saturated or unsaturated hydrocarbons both aliphatic and aromatic, and oxidation products mainly alcohols, but also aldehydes, ketones and esters are produced in the liquid-phase. For the $\mathrm{Ar} / \mathrm{H}_{2} \mathrm{O}$ plasma, the abundance of aldehydes and ketones is higher than of alcohols, in contrast to the $\mathrm{N}_{2} / \mathrm{H}_{2} \mathrm{O}$ plasma liquid products, where alcohols dominate. In the latter case, it is possible that the oxidation reaction rates in the liquid phase are decreased, due to slower diffusion rate of the reactive species caused by dynamic vaporisation. 


\section{Acknowledgement}

This work was funded from the "Nuclear Decommission Authority" and it is gratefully acknowledged. MP would also like to thank Dr Luke O' Brien, and Dr Xin Tu for their support and helpful discussions.

\section{References}

[1] Nunnally T, Tsangaris A, Rabinovich A, Nirenberg G, Chernets I and Fridman A International Journal of Hydrogen Energy 201439 11976-11989

[2] Tu X, Gallon H J, Twigg M V, Gorry P A and Whitehead J C Journal of Physics DApplied Physics 201144

[3] Odeyemi F, Pekker M, Rabinovich A, Fridman A A, Heon M, Mochalin V N and Gogotsi Y Ieee Transactions on Plasma Science 201240 1362-1370

[4] De Bie C, van Dijk J and Bogaerts A Journal of Physical Chemistry C 2015119 22331-22350

[5] Mlotek M, Sentek J, Krawczyk K and Schmidt-SzaÅ,owski K Applied Catalysis A: General 2009366 232-241

[6] Prieto G, Okumoto M, Shimano K, Takashima K, Katsura S and Mizuno A Industry Applications, IEEE Transactions on 200137 1464-1467

[7] Prieto G O, M. Takashima, K. Mizuno, A. Prieto, O. Gay, C. R. "A plate-to-plate plasma reactor as a fuel processor for hydrogen-rich gas production" Industry Applications Conference, 2001. Thirty-Sixth IAS Annual Meeting. Conference Record of the 2001 IEEE 2001:1099-1102 vol.2.

[8] Matsui Y, Kawakami S, Takashima K, Katsura S and Mizuno A Energy \& Fuels 2005 19 1561-1565

[9] Thagard S M P, G. Takashima, K. Mizuno, A. Plasma Science, IEEE Transactions on 201240 2106-2111

[10] Malik M A, Hughes, D., Malik, A., Xiao, S., Schoenbach, K. H. Plasma Chemistry and Plasma Processing 201333 271-279

[11] Hooshmand N R, Mohammad Reza Jahanmiri, Abdolhosein Taghvaei, Hamed Mohamadzadeh Shirazi, Meisam Industrial \& Engineering Chemistry Research 2013 52 4443-4449

[12] Taghvaei H J, Abdolhosien Rahimpour, Mohammad Reza Shirazi, Meisam Mohamadzadeh, Hooshmand, Navid Chemical Engineering Journal 2013226 384392

[13] Khani M R B, S. H. R. Yaghmaee, M. S. Hosseini, S. I. Shariat, M. Shokri, B. Fakhari, A. R. Nojavan, S. Tabani, H. Ghaedian, M. Plasma Science, IEEE Transactions on 201139 1807-1813

[14] Paulmier T and Fulcheri L Chemical Engineering Journal 2005106 59-71

[15] Czernichowski P, Czernichowski A. "Conversion of hydrocarbons assisted by gliding electric arcs" 2001.

[16] Mariotti D, Patel, J., Švrček, V., Maguire, P. Plasma Processes and Polymers 20129 1074-1085

[17] Abel B, Buck, U., Sobolewski, A. L., Domcke, W. Physical Chemistry Chemical Physics 201214 22-34

[18] Locke B R, Thagard, S. M. Plasma Science, IEEE Transactions on 200937 494-501 
[19] Brisset J-L, Baghdad, Benstaali,David, Moussa, Jean, Fanmoe, Estella, NjoyimTamungang Plasma Sources Science and Technology 201120034021

[20] Oehmigen K, Hoder, T., Wilke, C., Brandenburg, R., Hahnel, M., Weltmann, K. D., von Woedtke, T. Plasma Science, IEEE Transactions on 201139 2646-2647

[21] Prantsidou M "Plasma Methods for the Clean-up of Organic Liquid Waste" Chemistry: The University of Manchester 2013.

[22] Herron J T J. Phys. Chem. Ref. Data 199928 1453-1483

[23] van der Horst R M, Verreycken T, van Veldhuizen E M and Bruggeman P J Journal of Physics D-Applied Physics 201245

[24] Bruggeman P J, Sadeghi N, Schram D C and Linss V Plasma Sources Science \& Technology 201423

[25] Malik M A, Jiang C, Heller R, Lane J, Hughes D and Schoenbach K H Chemical Engineering Journal 2016283 631-638

[26] Cohen N, K.R. Westberg Journal of physical and chemical reference data 199120

[27] Inomata S, N, Washida The Journal of Physical Chemistry A 1999103 5023-5031

[28] Edvardsson D, Williams, Christopher F., Clary, David C. Chemical Physics Letters 2006431 261-266

[29] Campbell I M, Thrush, B. A. Proceedings of the Royal Society of London. Series A. Mathematical and Physical Sciences 1967296 222-232

[30] Kislov V V, Sadovnikov, A. I., Mebel, A. M. The Journal of Physical Chemistry A 2013117 4794-4816

[31] Krishnakumar E, Prabhudesai V S and Ram N B Journal of Physics: Conference Series 200788012073 